ISSN 0258-7122

Bangladesh J. Agril. Res. 40(4): 551-566, December 2015

\title{
ADOPTION OF RAISED BED TECHNOLOGY IN SOME SELECTED LOCATIONS OF RAJSHAHI DISTRICT OF BANGLADESH
}

\author{
M. A. MONAYEM MiAH ${ }^{1}$, MONIRUZZAMAN $^{2}$, S. HOSSAIN $^{3}$ \\ J. M. DUXBURY ${ }^{4}$, J. G. LAUREN ${ }^{5}$
}

\begin{abstract}
The study evaluated the adoption and farmers' practice of raised bed technology at farm level since the close of the Soil Management Collaborative Research Support Program (SMCRSP) through a follow-up survey conducted at Durgapur Upazila of Rajshahi district. Data for the study were collected from 195 adopters and 65 non-adopters through a pre-tested interview schedule during May, 2011. The survey findings showed that the raised bed technology had a strong demonstration effect and were adopted well (56\%) by the respondent farmers. The probability of adopting this technology was significantly influenced by extension contact, societal membership, and the number of male member in the household. Due to lack of machine, most farmers prepared raised bed by hand $(82.7 \%)$ without maintaining recommended bed size. The most cultivated crops on bed were wheat (cultivated by $97.95 \%$ farmers) maize $(27.69 \%)$ onion $(16.41 \%)$ and mungbean $(12.31 \%)$. Respondent farmers mentioned various positive benefits of bed technology and willing to continue this practice in future with increased area of land. This immerging technology increased cop productivity and farmers' income to some extent. To popularize the raised bed technology among farmers, bed planter should be available to the farmers and the positive benefits should be broadcasted in the mass media
\end{abstract}

Keywords: Bed planter, raised bed technology, adoption.

\section{Introduction}

Crop establishment through bed planting is a good technique in the farming systems of South Asia. This system is being extensively used in cultivating wheat both in India and Pakistan. This system was originated from Mexico's Yaqui Valley, where more than $90 \%$ of farmers had adopted this practice for wheat cultivation. Its use is very negligible in the eastern Gangetic Plains of South Asia, due to lack of machinery for smaller land holdings (Hossain et al., 2004a). Raised bed cultivation facilitates more optimum planting time for rice, wheat, maize, and pulses by providing timelier field access because of better drainage. Additionally, once the beds are established there are new opportunities to reduce crop turn-around time by re-using the same bed without tillage (Sayre, 2003). In addition, this system has many advantage, such as reducing the seed rate, requiring less irrigation water, imparting higher nitrogen use efficiency, reducing

\footnotetext{
${ }^{1 \& 2}$ Senior Scientific Officer, Agricultural Economics Division, Bangladesh Agricultural Research Institute (BARI), Joydebpur, Gazipur, ${ }^{3}$ Chief Scientific Officer, Regional Agricultural Research Centre, BARI, Jamalpur, Bangladesh ${ }^{4 \& 5}$ Professor, Cornell University, USA.
} 
crop lodging, and increasing crop yield over the conventional tillage/sowing systems (Meisner et al., 1992; Hobbs et al., 1997; Fahong et al., 2003; Lauren et al., 2008).

The mechanized bed planter creates a trapezoidal raised bed and can perform seeding operations on the top of the bed simultaneously in one operation behind a power tiller. There is also a provision of fertilizer application along with seed sowing. The farm level performance of bed planter was tested for wheat, maize, mungbean, and other crop cultivation in different areas of Dinajpur and Rajshahi districts. On-farm research results revealed that this system saved 20-34\% irrigation water, 16-69\% planting cost, and ensured higher crop yield compared to conventional system (Hossain et al., 2010). The BCR of wheat cultivation on raised bed and permanent bed were 4.5 and 4.7 which was $41 \%$ and $47 \%$ higher than conventional method respectively (Hossain et al., 2004b). Lauren, et al. (2008) found mean yield response to $\mathrm{N}$ fertilization greater on raised beds than on the flat, and greater with rice than wheat. They also recorded consistent improvements in yield and reductions in irrigation inputs, together with cost savings in labour, land preparation, fertilizer, and seed inputs, on permanent beds which convinced a group of Bangladeshi farmers to adopt this innovative technology.

Realizing the importance of the raised bed for improved crop production, the scientists of Cornell University (USA) in collaboration with Bangladesh Agricultural Research Institute (BARI) and CIMMYT introduced the raised bed technology through the SM CRSP project (2003-2008) entitled 'Enhancing technology adoption for the rice-wheat cropping system of the Indo-Gangetic Plains'. The focus area for the initial work was in Rajshahi and Natore districts. The technology was disseminated to 26 farmers from Duary, Santospur and Durgapur areas, who were interested in reducing their labor/input costs and diversifying their cropping system for more profitable production. All the farmers received hands-on training in the use of the power tiller with the bed former attachment and then used the knowledge and a bed former on loan from the project to compare raised bed versus conventional flat cultivation in a wheatmungbean-rice rotation on their own farms. A research scientist from BARIRajshahi provided technical backstopping and monitoring support throughout.

The participating farmers were enthusiastic about raised bed because the practice improved livelihoods and food security for their families. Interest in the raised bed technology expanded beyond the initial group to farmers in the surrounding communities, who were part of a federation of 22 community groups which had formed from CARE farmer field schools. One farmer group took the lead to disseminate the raised bed technology to the other farmers through rallies and hands-on equipment trainings. Some group members obtained loan from a local NGO (CAR) to purchase the equipment and then provided bed formation services on a for-hire basis. By the end of the SM CRSP project in 2008, the use of raised bed cultivation had expanded from 26 farmers on 4.05 ha to over 900 
farmers on 196.76 ha. In 2010, Cornell University, USA initiated the Food for Progress Project for Bangladesh with funding from the US Department of Agriculture. The objective of this project was to continue dissemination of the raised bed technology for smallholder farmers in the drought prone region of Rajshahi Division. Feedback from farmers who were involved with raised bed from the SM CRSP phase can be used to ensure the success of the new project.

With this background, a follow-up survey in the introduction area is needed to understand farmers' practice of raised bed since the close of the SM CRSP project. Therefore, an attempt was made in this study to document the status of current use of raised bed technology, farmers' perceptions, and overall impact of this technology at farm level. The findings of the study will be very much helpful to the farmers, researchers, policy makers and donor agency for wider expansion of this proven technology throughout the country.

\section{Objectives:}

1. To know the present status of using raised bed technology for cultivating crops at the farm level.

2. To assess the status of adoption of the raised bed technology at farm level and to find out the factors affecting its adoption and non-adoption.

3. To assess farmers' perceptions on the impact of raised beds on input use and income through higher productivity.

\section{Methodology}

Sampling and data collection: The study followed purposive sampling in order to select study areas and sample raised bed using farmers. At the first stage of sampling, the study selected those areas where the raised bed technique of crop production was first introduced through SM CRSP between 2003 and 2008. Besides, the primary focus population of this survey was those farmers who are currently using the raised bed practice or have used the technique in the recent past. Thus, a total of 13 villages namely Alipur, Uzalkhalshi, Namordakhali, Nandigram, Nowapara, Sunpukuria, Shyampur, Sakundhighi, Dorampur, Debipur, Usappur, Tiokhum, and Kashipur under Durgapur Upazila of Rajshahi district were selected purposively for the study.

A total of 195 raised bed technology using farmers taking 15 farmers from each village were selected for interview. Again, 65 non-using farmers taking five farmers from each village were interviewed to know the causes of non-adoption of this technology. Thus the total number of sample was 260. Data were gathered through a pre-tested interview schedule during May, 2011.

Analytical technique: The collected data were scrutinized, edited, tabulated and analyzed for fulfilling the objectives of the study. Data were mostly analyzed 
through tabular method using descriptive statistics. The level of adoption of the raised bed technology was measured by the following formula.

$$
\text { Technology adoption }(\%)=\frac{\text { Total number of adopted farm families }}{\text { Total number of farm families }} \times 100
$$

Probit regression model has been extensively used by agricultural production and farming systems economists for studying and analyzing farmer adoption and diffusion of agricultural interventions. Therefore, the following empirical Probit regression model was used to ascertain the probability of adoption of raised bed technology at farm level.

$$
\mathrm{A}_{\mathrm{i}}=\alpha+\beta_{\mathrm{i}} \mathrm{X}_{\mathrm{i}}+\ldots \ldots . . \mathrm{U}_{\mathrm{i}}
$$

Where,

$\mathrm{A} i=$ Farmers adopting raised bed technology; (If, Adopted $=1 ;$ Otherwise $=$ $0)$

$\alpha=$ Intercept

$\mathrm{Xi}=$ Independent variables $(\mathrm{i}=1,2,3$------6)

$\mathrm{Ui}=$ Error term; and

The independent variables were:

$\mathrm{X}_{1}=$ Age of the respondent (year)

$\mathrm{X}_{2}=$ Male member (No/household)

$\mathrm{X}_{3}=$ Education (Year of schooling)

$\mathrm{X}_{4}=$ Total cultivated land (in decimal)

$\mathrm{X}_{5}=$ Extension contact (Scores, 0-20)

$\mathrm{X}_{6}=$ Membership of the society (Scores, 0-24)

\section{Results and Discussion}

\section{Present Status of Raised Bed Cultivation at Farm Level}

Crops and bed size: Using raised bed technique farmers in the study areas cultivated various crops such as wheat, lentil, mungbean, sesame, onion, maize and rice. The highly cultivated crop was wheat followed by maize, rice and onion. Most of the farmers prepared bed by hand (82.7\%) without maintaining recommended bed size. Few beds $(11.3 \%)$ were prepared by bed planters. The bed widths were found to vary from crop to crop. They maintained the highest bed width for onion $(73.9 \mathrm{~cm})$ and the lowest for wheat $(42.8 \mathrm{~cm})$. Detailed information on bed size maintained by the respondent farmers has been shown in Table 1. 
Many farmers in the study areas started cultivating crops on raised bed from 2003 and reported to be continued up to 2011. After ending the SMCRSP project activities many farmers started using bed technology due to its strong and positive demonstration impact. Table 2 further shows that the average length of using bed technology was found to vary from crop to crop. The longest period involvement of the farmers was reported to be with T.Aman (5 years) followed by mungbean ( 4.42 years) and onion (4.09 years).

Table 1. Information on cultivated crops and bed size in using raised bed technology.

\begin{tabular}{|c|c|c|c|c|c|c|c|}
\hline \multirow{2}{*}{$\begin{array}{l}\text { Crops grown } \\
\text { with beds }\end{array}$} & \multicolumn{2}{|c|}{$\begin{array}{l}\text { Respondent } \\
(\mathrm{n}=195)\end{array}$} & \multirow{2}{*}{$\begin{array}{l}\text { Width of } \\
\text { bed }(\mathrm{cm})\end{array}$} & \multicolumn{3}{|c|}{$\begin{array}{l}\text { Raised bed prepared by } \\
(\%)\end{array}$} & \multirow{2}{*}{$\begin{array}{l}\text { Cultivation } \\
\text { length (yr) }\end{array}$} \\
\hline & Number & $\%$ & & Machine & Hand & Both & \\
\hline 1. Lentil & 4 & 2.05 & 63.0 & - & 100 & - & 1.50 \\
\hline 2. Wheat & 191 & 97.95 & 42.8 & 3.7 & 89.5 & 6.8 & 3.52 \\
\hline 3. Mungbean & 24 & 12.31 & 48.1 & 37.5 & 54.2 & 8.3 & 4.42 \\
\hline 4. Jute & 9 & 4.62 & 44.0 & 22.2 & 77.8 & - & 3.78 \\
\hline 5. Sesame & 5 & 2.56 & 45.7 & 40.0 & 40.0 & 20.0 & 1.40 \\
\hline 6. Onion & 32 & 16.41 & 73.9 & 3.1 & 96.9 & - & 4.09 \\
\hline 7. Maize & 54 & 27.69 & 49.5 & 9.3 & 85.2 & 5.6 & 3.02 \\
\hline 8. Rice & 36 & 18.47 & 17.6 & 25.0 & 69.5 & 7.4 & 3.61 \\
\hline - Boro & 18 & 9.23 & 44.9 & 5.6 & 88.9 & 5.6 & 3.33 \\
\hline - Aus & 9 & 4.62 & 45.7 & 44.4 & 55.6 & - & 2.78 \\
\hline - T.Aman & 9 & 4.62 & 43.7 & 44.4 & 44.4 & 11.1 & 5.00 \\
\hline Overall & 391 & -- & -- & 11.3 & 82.7 & 6.1 & -- \\
\hline
\end{tabular}

Table 2. Information regarding farmers' raised bed in the study areas.

\begin{tabular}{lcc}
\hline \multicolumn{1}{c|}{ Particular } & No. of respondent & \% of responce \\
\hline Tillage operation (No./bed) & 195 & 3.2 \\
Cost of bed preparation (Tk/decimal) & 195 & 38.0 \\
Bed-to-bed distance (cm) & 195 & 18.1 \\
Furrow-to-furrow distance (cm) & 195 & 43.4 \\
Measuring devices or instruments & 195 & \\
- Scale & 11 & 5.6 \\
- Ware/rope & 23 & 11.8 \\
- Stick & 134 & 68.7 \\
- Spade & 14 & 7.2 \\
- Based on idea & 9 & 4.6 \\
- Foot & 4 & 2.1 \\
\hline
\end{tabular}

Adopting farmers generally plough their lands 3-4 times with country plough or power tiller before preparing raised bed. The average cost of land preparation was Tk. 9,391 per ha. Irrespective of crops, the average distances from bed-tobed and furrow-to-furrow were reported to be $18.1 \mathrm{~cm}$ and $43.4 \mathrm{~cm}$. They used 
measuring scale, rope/ware, stick, spade and foot in measuring bed-to-bed and furrow-to-furrow distance. In most cases, they used sticks (68.7\%) for measuring the distances mentioned above. At first, they measure two sticks by hand and these sticks are used later to make furrow between beds with the help of rope/ware. Sometimes, they dig furrow between beds with spade and in that case the distance of furrow is equal to the width of the spade. Furrow distance was sometime determined through farmers' foot (Table 2).

Causes of bed preparation by hand: Preparation of raised bed through bed planter has many advantages. Bed planter creates a trapezoidal raised bed and can perform seeding operations on the top of the bed simultaneously in one operation. It has also fertilizer application provision along with seed sowing. Machine made raised bed can save 20-34\% irrigation water, 16-69\% planting cost and ensure less human labour (Hossain et al. 2010a). Nevertheless, many farmers were found enthusiastic toward using bed planter in the study areas. Despite these advantages, most of the farmers reported to prepare raised bed by hand. The principal reason was the non-availability of bed planter $(96.41 \%)$ in the study areas. A few farmers have access to bed planter use due to close association with BARI scientists.

About $7 \%$ farmers of this category complained that bed planter was scarce at the time of need and because of that reason they prepared bed by hand. Some bed planter using farmers could not bring bed planter to their fields due to lack of road. Sometimes it is difficult to bring bed planter to the desired fields crossing other crop fields. Due to these types of constraints $3.59 \%$ farmers prepared raised bed by hand. Few farmers opined that broadcasting of seed by hand was better than that of bed planter. Bed and furrow length can easily be maintained by hand which was mentioned by $3.08 \%$ farmers (Table 3 ).

Table 3. Reasons for preparing raised bed by hand (multiple response).

\begin{tabular}{l|r|r}
\hline Reason & Frequency & Percentage \\
\hline Number of respondent $(n)$ & 195 & 100 \\
\hline 1. Non-availability of bed planter or power tiller & 188 & 96.41 \\
2. Scarcity of bed planter at the time of need & 13 & 6.67 \\
3. Constraints to using bed planter & 7 & 3.59 \\
4. Hand seed sowing is better than bed planter & 9 & 4.62 \\
5. Bed and furrow length can easily be & 6 & 3.08 \\
maintained & & \\
\hline
\end{tabular}

Modifications made in bed technology: At the initial stage of using bed technology, the recommended widths of bed and furrow were $127 \mathrm{~cm}$ and $63.5 \mathrm{~cm}$ respectively for wheat, maize and onion. Besides, the recommended widths were $101.6 \mathrm{~cm}$ and $50.8 \mathrm{~cm}$ for mungbean. But a good proportion of the adopting farmers have modified these widths of bed and furrow from the way they originally learnt about it from scientists or any other person (Table 2). Table 4 shows that $30.8 \%$ adopting farmers told that they modification their bed size 
(width of bed and furrow). The rest $69.2 \%$ of adopting farmers did not modify the bed size because they learnt and adopted bed technology with modified forms that need no modification. Table 4 further shows that $29.2 \%$ of the adopting farmers shortened bed width whereas only $8.7 \%$ shortened furrow width. Some adopters also shortened plant to plant distance, changed measuring instrument and applied more fertilizer than recommended dose.

Table 4. Percent responses on modifications made in the raised bed technology.

\begin{tabular}{l|c|c}
\hline \multicolumn{1}{c|}{ Particular } & Frequency & Percentage \\
\hline \multicolumn{1}{c}{ Number of respondent $(n)$} & 195 & 100 \\
\hline Responses on modifications & 60 & 30.8 \\
Yes & 135 & 69.2 \\
No & & \\
\hline Types of modifications & 57 & 29.2 \\
1. Shorten bed width & 17 & 8.7 \\
2. Shorten furrow width & 4 & 2.1 \\
3. Shorten plant to plan distance & 2 & 1.0 \\
4. Change measuring instrument & 3 & 1.5 \\
5. Apply more fertilizer &
\end{tabular}

Sources of assistance: The respondent farmers mentioned various sources from which they received assistance for preparing raised bed at the first time. The highly reported source was neighbouring farmers (56.9\%). Generally farmers became enthusiastic toward bed technology observing positive benefits of the technology and later seek assistance from neighboring farmers to prepare bed for crop cultivation. About 26\% farmers received assistance from local BARI scientists in preparing bed in the initial stage of using bed technology. Some respondents prepared raised bed at the first time without taking any help from others. They observed the technique of preparing raised bed from others and did it themselves. Service provider, relatives, and CARE personnel had some contribution to assist farmers in preparing seed bed in the study areas (Table 5).

Table 5. Sources of assistance in preparing raised bed at the first time

\begin{tabular}{lcc}
\hline \multicolumn{1}{c|}{ Sources of assistance } & No. of respondent & \% of responces \\
\hline 1. Neighbouring farmer & 111 & 56.9 \\
2. BARI scientist & 50 & 25.6 \\
3. Self or observed others' field & 19 & 9.8 \\
4. Sub Assistant Agriculture Officer & 6 & 3.1 \\
5. IPM club & 3 & 1.5 \\
6. Service provider & 2 & 1.0 \\
\hline
\end{tabular}




\begin{tabular}{lcc}
\hline 7. Relatives & 2 & 1.0 \\
8. CARE personnel & 2 & 1.0 \\
\hline \multicolumn{1}{c}{ All sources } & 195 & 100 \\
\hline
\end{tabular}

\section{Adoption of Raised Bed Technology and Its Determinants}

Adoption status: In order to reduce input costs and diversify cropping system for more profitable crop production, the scientists of BARI in collaboration with Cornell University (USA) and CIMMYT disseminated the raised beds technology through SMCRSP project among the farmers of the study areas during the period from 2003 to 2008 . After that period many farmers were found to practice this production technique for its versatile advantages. The survey result showed that on an average $56 \%$ of the respondent farm families adopted raised based technology for cultivating different types of crops. Table 6 showed that the highest level of adoption was observed at Sunpukur village $(76.3 \%)$ followed by Namudarkhali (73.5\%) and Nawapara (69\%).

Table 6. Status of adoption of raised bed technology for crop cultivation.

\begin{tabular}{lcccc}
\hline \multicolumn{1}{c}{ Name of village } & Total farm household & Total adopting farm & \% of adopter \\
\hline 1. Alipur & 613 & 312 & 50.9 \\
2.Debipur & 897 & 344 & 38.4 \\
3. Darmapur & 473 & 171 & 36.2 \\
4. Isabpur & 310 & 147 & 47.4 \\
5. Kashipur & 303 & 180 & 59.4 \\
6. Namudarkhali & 347 & 255 & 73.5 \\
7. Nandigram & 928 & 515 & 55.5 \\
8. Nawapara & 449 & 310 & 69.0 \\
9. Shampur & 530 & 316 & 59.6 \\
10. Sukandipur & 122 & 48 & 39.3 \\
11. Sunpukur & 940 & 717 & 76.3 \\
12.Tiorkuri & 116 & 56 & 48.3 \\
13. Uzalkhalsi & 591 & 330 & 55.8 \\
\hline \multicolumn{1}{c}{ All villages } & $\mathbf{6 6 1 9}$ & $\mathbf{3 7 0 1}$ & 55.9 \\
\hline
\end{tabular}

Determinants of adoption: The adoption of raised bed technology is likely to be influenced by different socio-economic factors. At first nine explanatory variables, such as age, male family member, education, cultivated land, extension contact, membership with social organization, cosmopolitness, contact with mass media, and innovativeness of the respondent farmers were hypothesized to be major determinants of raised bed technology adoption in the study areas. After testing the level of significance, six variables were finally included in the model. Table 7 shows that age, education, and farm size had positive influence on bed technology adoption but these influences were not significant at desired level. The reason behind this relationship was that farmers with younger age, lower 
education, and smaller holdings might be the adopters of this bed planting technology in the study areas.

Many respondent farmers opined that crop cultivation on raised bed required more human labour compared to conventional flat method. The coefficient of variable household male member is positive and highly significant at $1 \%$ level implying that the farm families having higher male member adopted bed technology more than that of families having less male member (Table 7). It is important to note that female members in the study areas do not usually work in the field. Marginal coefficient indicates that if the male member in the family is increased $10 \%$ the probability of adopting raised bed technology will be $1.032 \%$ (Table 8).

Table 2 further shows that respondent's contact with different extension personnel such as Agriculture Officer, Sub Assistant Agriculture Officer, BARI scientist and neighbouring farmers had a positive and highly significant relationship with the probability of adopting bed technology. The probability of adopting bed technology will be increased by $3.36 \%$ if the extension contact is increased by $100 \%$ (Table 8 ).

It was observed that the respondent farmers who involved different social organizations like farmers' co-operative society, IPM club, youth development society, school/Madrasa (religious school)/mosque managing committee, etc. adopted bed technology more than the farmers who involved less with social organizations. Probit estimate also shows that there is a positive and significant relationship between bed technology adoption and involvement with the society. The probability of adopting bed technology will be increased by $5.22 \%$ if the respondent's involvement was increased by $100 \%$ (Table 8 ).

Table 7. Maximum likelihood estimates of variable determining adoption of raised bed technology among respondent farmers.

\begin{tabular}{l|c|c|c|c}
\hline \multicolumn{1}{c|}{ Explanatory variable } & Coefficient & $\begin{array}{c}\text { Standard } \\
\text { Error }\end{array}$ & z-statistic & $\begin{array}{c}\text { Probability } \\
(\mathrm{P}>\mathrm{z})\end{array}$ \\
\hline Constant & - & & & \\
Age (year) & $1.3541^{* * *}$ & 0.52117 & -2.60 & 0.009 \\
Male member (No./HH) & 0.0039 & 0.00904 & 0.44 & 0.660 \\
Education (year of schooling) & $0.3804 * * *$ & 0.00904 & 3.24 & 0.001 \\
Cultivated land (decimal) & 0.0037 & 0.02283 & 0.16 & 0.873 \\
Extension contact (score; 0-20) & 0.0004 & 0.00089 & 0.45 & 0.654 \\
Membership of the society (score; 0-24) & $0.1239 * * *$ & 0.03075 & 4.03 & 0.000 \\
\hline
\end{tabular}

Note: No. of observation $=260 ;$ LR Chi-square $(6)=50.86$; Log likelihood $=$ 120.77505 .

***Co-efficient significant at $1 \%$ level. 
Reasons for not adoption: A good number of non-adopting farmers were asked to answer the reasons of not adopting raised bed technology for crop cultivation. They mentioned different reasons for not adopting raised bed technology. The highest proportion of the respondent farmers (69.2\%) did not adopt the technology due to higher labour required for bed preparation and seed sowing at the initial stage of cultivation. Majority of the respondents $(67.7 \%)$ considered it as a laborious and cumbersome job since there are scarcity of labour prevailed in their households as well as in the study areas. A good percentage of farmers (47.7\%) also reported the lacking of awareness and technical know-how about the bed technology behind their non-adoption of this technology. Some respondent farmers considered broadcasting of seed on flat field to be a better technique compared to bed planter since it requires less labour and time (Table 9).

Table 8. Marginal effect after probit.

\begin{tabular}{l|c|c|c|c}
\hline \multicolumn{1}{c|}{ Explanatory variable } & dy/dx & $\begin{array}{c}\text { Standard } \\
\text { Error }\end{array}$ & z-statistic & $\begin{array}{c}\text { Probability } \\
(\mathrm{P}>\mathrm{z})\end{array}$ \\
\hline Age (year) & 0.00108 & 0.00245 & 0.44 & 0.660 \\
Male member (No./HH) & $0.10322 * * *$ & 0.03090 & 3.34 & 0.001 \\
Education (year of schooling) & 0.00099 & 0.00620 & 0.16 & 0.873 \\
Cultivated land (decimal) & 0.00011 & 0.00024 & 0.45 & 0.652 \\
Extension contact (score; 0-20) & $0.03364 * * *$ & 0.00834 & 4.03 & 0.000 \\
Membership of the society (score; 0-24) & $0.05224 * * *$ & 0.01896 & 2.75 & 0.006 \\
\hline
\end{tabular}

Table 9. Reasons for not adopting raised bed technology (multiple responses).

\begin{tabular}{l|c|c}
\hline Reasons & Frequency & Percentage \\
\hline Number of respondent $(N)$ & 65 & 100 \\
\hline 1. Required much labour & 45 & 69.2 \\
2. Bed preparation is a laborious and cumbersome job & 44 & 67.7 \\
3. Lack of awareness or know-how about bed technology & 31 & 47.7 \\
4. Scarcity of bed planter in the area & 19 & 29.2 \\
5. Required longer time & 17 & 26.2 \\
6. Hand broadcasting of seed is better than bed planter & 13 & 20.0 \\
\hline
\end{tabular}

\section{Farmers' Perceptions in Using Raised Bed Technology}

Farmers' observation: Crop establishment through raised bed technology has many advantages such as higher crop yield, reduction in input use, reduction in production cost over conventional practice. The respondent farmers in the study areas observed many positive benefits of the technology during crop production. The highest proportion of farmers $(81.5 \%)$ told that they got much higher crop yield due to use raised bed technology. The results of on-farm experiments (Hossain et al., 2004b; Lauren et al., 2008) also supported this statement. Another important observation $(77.9 \%)$ of the farmers was that the established 
crops on raised bed were not attacked by rats. Sometimes few plots were attacked by rats, but it could easily be controlled manually. Many farmers mentioned that raised bed technology could successfully reduce the amount of various production inputs like irrigation water, seed, fertilizer, and labour. These observations were also similar to the observations made by Hossain et al. (2004b) and Lauren et al. (2008). The respondent farmers in the study areas mentioned that intercultural operations like weeding and insecticide application are become easy due to cultivate crop on raised bed. The other positive observations of the farmers were erectness of plant; lower cost of production; and birds can't take seed from field (Table 10).

Table 10. Farmers' observations about raised bed technology in the study areas.

\begin{tabular}{lcc}
\hline \multicolumn{1}{c|}{ Observation } & Frequency & Percentage \\
\hline Positive observations $(n=195)$ & & \\
\hline 1. Higher crop yield & 159 & 81.5 \\
2. Less attack by rats/ Easy to control rats & 152 & 77.9 \\
3. Require less irrigation water & 147 & 75.4 \\
4. Crop weeding is easy & 107 & 54.9 \\
5. Require less amount of seed & 101 & 51.8 \\
6. Crop harvesting is easy & 68 & 34.9 \\
7. Require less fertilizer & 52 & 26.7 \\
8. Insecticide application is easy & 42 & 21.5 \\
9. Less infestation by insect-pest & 31 & 15.9 \\
10. Reduce crop lodging & 25 & 12.8 \\
11. Require less labour & 14 & 7.2 \\
12. Lower cost of production & 11 & 5.6 \\
13. Birds can't take seed from field & 5 & 2.6 \\
\hline Negative observations $(n=133)$ & & \\
\hline 1. No negative side is observed & 62 & 31.8 \\
2. Required higher labour & 125 & 94.0 \\
3. Require higher amount of irrigation water & 22 & 16.5 \\
4. Seed dropping is disrupted in case machine & 4 & 3.0 \\
5. Planter can't prepare bed in the field side & 6 & 3.8 \\
\hline
\end{tabular}

Table 10 further reveals that $31.8 \%$ respondent farmers did not observe any negative side of the raised bed technology. The rest $68.2 \%$ farmers mentioned some negative sides of this technology. Of them $94 \%$ mentioned about the higher requirement of labour for bed preparation and seeding through bed planter compared to conventional technique. It is important to state here that bed planter requires less number of labours and it has already been proved in many on-farm experiments. But, most respondent farmers prepared raised bed manually for crop production due to non-availability of bed planter. Bed technology has already been proved as a water saving technology, but some farmers claimed that this 
technique of cultivation needs more irrigation water than that of conventional technique. Such response might be due to their ignorance.

Future plan on raised beds use: The bed technology practicing farmers were asked to answer whether they increase land area for cultivating crops on raised bed or not in the next year. In this respect about $88 \%$ farmers wanted to increase area in the next year. They wanted to increase an average area of 28.5 decimal for the next year (Table 11). They mentioned many reasons for increasing land for cultivating crops on beds. These reasons were mostly similar to the positive observations of the farmers regarding bed use (Table 10). Only $12.3 \%$ adopting farmers will not increase area due to some reasons such as lack of suitable land $(100 \%)$, scarcity of land for mortgage in $(37.5 \%)$ and lack of hired labour $(12.5 \%)$.

Table 11. Reasons for increasing and not increasing crop cultivation on raised beds.

\begin{tabular}{lcc}
\hline \multicolumn{1}{c|}{ Particulars } & Frequency & Percentage \\
\hline Responses on increase crop cultivation on bed & $n=195$ & 100 \\
Yes & 171 & 87.7 \\
No & 24 & 12.3 \\
Amount of land area increased (decimal) & 171 & 28.5 \\
\hline Reasons for not increasing crop area & & \\
1. Lack of suitable land & 24 & 100 \\
2. Scarcity of land for mortgage in & 9 & 37.5 \\
3. Lack of hired labour & 3 & 12.5 \\
\hline
\end{tabular}

Table 12. Actions needed for increasing adoption of raised bed technology in future.

\begin{tabular}{l|c|c}
\hline \multicolumn{1}{c|}{ Type of actions } & Frequency & Percentage \\
\hline Number of respondent $(n)$ & 195 & 100 \\
\hline $\begin{array}{l}\text { 1. Raised bed planter should be made locally available } \\
\text { 2. Provide training to the farmers on raised bed } \\
\text { technology }\end{array}$ & 165 & 84.6 \\
3. Broadcast positive impacts of RBT through mass & 154 & 79.0 \\
media & 59 & 30.3 \\
4. Provide soft loan to the enthusiastic farmers & 41 & 21.0 \\
5. Demonstrate bed planting technique in new areas & 29 & 14.9 \\
6. Provide subsidy to the enthusiastic farmers & 10 & 5.1 \\
7. Develop effective monitoring mechanism for & 4 & 2.1 \\
technology disseminators & & \\
\hline
\end{tabular}

Actions needed for higher adoption: The respondent farmers suggested many ways and means for increasing the adoption of this promising and versatile technology at farm level. The highest proportion of respondent $(84.6 \%)$ mentioned that the government should make bed planter available to the farmers since it reduces input use and increases crop productivity. Seventy nine percent 
farmers suggested the government to provide practical and field oriented training on raised bed technology to the enthusiastic farmers. Mass media like radio, TV and daily newspaper can play important role in creating awareness and motivating farmers towards new technology.

Therefore, the government should broadcast the positive impact of raised bed technology using mass media suitable for farmers. In order to increase the use of bed planter soft loan and subsidy may be provided to the interested farmers. About $15 \%$ farmers stresses on the demonstration of bed planting technique in other new areas. Monitoring is important to keep farmers' interest toward new technology adoption and its continuous use. Some respondent farmers complained that scientists/extension personnel involved in technology dissemination did not come to the farmer after the completion of the project. Therefore, few farmers also gave emphasis on developing effective monitoring mechanism for technology disseminators (Table 12).

\section{Impact of Raised Bed Technology}

Raised bed technology has created a positive impact on crop productivity, income and livelihood of the farmers. Survey results revealed that one hundred percent respondent farmers opined that bed technology brought them positive impacts to some extent on household income, household food security and livelihood improvement. Most farmers mentioned about the livelihood improvement but types of improvements were not clear to them since it was associated with overall socioeconomic development of the society. Respondent farmers also stated various positive impacts of raised bed technology. About $70 \%$ farmers experienced with higher crop productivity. The results of the last 8 years on-farm experiment revealed that crop yield on new raised bed always higher than permanent bed (Hossain et al., 2010; Hossain et al., 2004). More than 82\% farmers received increased income due to use raised bed technology. The amount of food intake was also increased for some of the respondent households (Table 13).

Table 13. Responses on the impact of bed technology on crop productivity and income of the respondent farmers.

\begin{tabular}{l|c|c}
\hline \multirow{2}{*}{ Particulars } & \multicolumn{2}{c}{ Farmers' responses } \\
\cline { 2 - 3 } & Frequency & Percentage \\
\hline Impacts on income & $n=195$ \\
Positive impact & 195 & 100 \\
No impact & - & - \\
\hline Type of positive impacts & 136 & 69.7 \\
1. Increase in crop productivity & 160 & 82.1 \\
2. Increase in household income & 113 & 57.9 \\
3. Increase in livelihood standard & 26 & 13.3 \\
4. Increase in food intake &
\end{tabular}


Raised bed technology has also created a significant impact on input use. The preparation of raised bed by hand needs higher labour compared to bed planter. That's why majority of the respondent farmers (75.4\%) opined that crop cultivation on bed needs higher human labour compared to conventional system. Some farmers argued that at the stage of bed preparation this technique required higher labour but intercultural operations and harvesting need less labour than that of conventional system. As a result bed technology reduces labour requirement in crop cultivation. About $22 \%$ farmers stated this view regarding labour use. Bed technology also reduces the use of seed, fertilizer and irrigation water per unit area (Hobbs et al., 1997; Fahong et al., 2003). Majority of the respondent farmers reported that bed technology reduced the use of seed (94.4\%), fertilizer $(73.3 \%)$, and irrigation water $(61 \%)$. Few farmers $(21 \%)$ argued that this new technology required higher irrigation water because the furrow between beds contained more water and the rate of evaporation from bed is much higher than that of conventional system (Table 14).

Table 14. Impact of raised bed technology on input use.

\begin{tabular}{l|c|c|c|c|c|c}
\hline \multirow{2}{*}{ Inputs } & \multicolumn{2}{|c|}{ Frequency of responses $(n=195)$} & \multicolumn{3}{c}{ \% of responses } \\
\cline { 2 - 7 } & Increased & Constant & Decreased & Increased & Constant & Decreased \\
\hline 1. Use of labour & 147 & 6 & 42 & 75.4 & 3.1 & 21.5 \\
2. Use of seed & - & 11 & 184 & - & 5.6 & 94.4 \\
3. Use of fertilizer & 9 & 43 & 143 & 4.6 & 22.1 & 73.3 \\
4. Use of water & 41 & 35 & 119 & 21.0 & 18.0 & 61.0 \\
\hline
\end{tabular}

Table 15. Comparative scenario of productivity and profitability of wheat and maize cultivation under two cultivation systems.

\begin{tabular}{|c|c|c|c|}
\hline Particular & Bed system & Conventional system & $\%$ higher or lower \\
\hline \multicolumn{4}{|l|}{ A. Wheat } \\
\hline Yield (t/ha) & 4.3 & 2.3 & 87 \\
\hline Total cost (Tk/ha) & 13540 & 10270 & 32 \\
\hline Gross benefit (Tk/ha) & 60903 & 33403 & 82 \\
\hline Benefit cost ratio (BCR) & 4.5 & 3.2 & 41 \\
\hline \multicolumn{4}{|l|}{ B. Maize } \\
\hline Yield (t/ha) & 9.7 & 7.8 & 24 \\
\hline Total cost $(\mathrm{Tk} / \mathrm{ha})$ & 20561 & 22166 & -7 \\
\hline Gross benefit (Tk/ha) & 61164 & 49764 & 23 \\
\hline Benefit cost ratio (BCR) & 2.98 & 2.2 & 35 \\
\hline
\end{tabular}

Source: Adopted from Hossain et al., 2004.

The use of raised bed technology is cost-effective and profitable to most of the farmers because this technology ensures lower input use in one hand and higher crop yield on the other. Hossain et al., (2004) found that wheat cultivation on 
raised bed incurred 32\% higher cost compared to conventional system. But the cost of maize cultivation on bed is $7 \%$ lower than that of conventional system. In both the cases, the benefits are much higher compared to the conventional system.

\section{Conclusion}

The study has evaluated farmers' practice of raised bed technology since the close of the SM CRSP project through a follow-up survey. The survey findings show that the raised bed technology has a strong and positive demonstration effect and has been adopted well by the farmers of the study areas. The probability of adopting this technology is significantly influenced by extension contact, societal membership and number of male member in the household. Due to lack of machine, most farmers prepare raised bed by hand without maintaining recommended bed size. The most cultivated crops on bed are wheat, maize, onion and mungbean. Responded farmers have mentioned various positive benefits of raised bed cultivation and willing to continue this practice in future with increased area of land. This versatile and immerging technology has created a positive impact on crop productivity and farmers' income to some extent.

\section{Recommendations}

Based on the findings of the study, Government should take the following steps for wider adoption of this technology.

a) Bed planter should be available to the farmers since it reduces input cost and increases crop productivity.

b) Hand-on training on raised bed technology should be provided to the enthusiastic farmers.

c) The positive impacts of raised bed technology should be broadcasted among farmers through mass media in creating awareness towards this new technology.

d) Soft loan and subsidy may be provided to the interested farmers for increasing the use of raised bed planter.

e) Monitoring is important to keep farmers' interest toward new technology adoption and its continuous use. Therefore, emphasis should be given on developing effective monitoring mechanism for technology disseminators.

Acknowledgements: We wish to acknowledge the financial support of Cornell University, USA to conduct the study. We also appreciate the help of many others, both individuals and institutions, during conducting this study and regret our inability to acknowledge them all individually. 


\section{References}

Fahong, W., W. Xuquing and K. D. Sayre. 2003. Comparison study on two different planting methods for winter wheat in China. Bed planting course, CIMMYT, Mexico.

Hobbs, P. R., G. S. Giri and P. Grace. 1997. Reduced and zero tillage options for the establishment of wheat after rice in South Asia. RCW Paper No. 2. Mexico, D.F.: Rice-Wheat Consortium for the Indo-Gangetic Plains and CIMMYT.

Hossain, M. I., M. S. Islam, I. Hossain, C. A. Meisner and M. S. Rahman. 2010. Seeding performance of two wheel tractor operated bed planter for cereal crop establishment. International Journal of Energy Machinery 3(1): 63-69.

Hossain, M. I., M. A. Sufian, M. A. Z. Sarker, E. Haque and A. B. M. M. Rahman. 2004a. Power tiller operated bed planter for improved crop establishment. Journal of Science and Technology 2:17-23.

Hossain, M. I., C. A. Meisner, M. H. Rashid, M. A. Sufian and M. A. R. Akanda. 2004b. Development and test of power tiller operated bed planter for upland crop establishment. Bangladesh J. Agril. Res. 29(1):29-36.

Lauren, J. G., G. Shah, M. I. Hossain, A. S. M. H. M. Talukder, J. M. Duxbury, C.A. Meisner and C. Adhikari. 2008. Research station and on-farm experiences with permanent raised beds through the Soil Management Collaborative Research Support Program. In: Proceedings of a workshop title "Permanent beds and rice-residue management for rice-wheat systems in the Indo-Gangetic Plain" held in Ludhiana, India, 7-9 September 2006. Australian Centre for International Agricultural Research, Canberra, Australia. P-124-132.

Meisner, C. A., E. Flores, K. D. Sayre, I. Ortiz-Monasterio, D. Byerlee. 1992. Wheat Production and Grower Practices in the Yaqui Vally, Sonara, Mexico. Wheat Special Report No. 6. CIMMYT, Mexico DF.

Sayre, K. D. 2003. Raised bed System of Cultivation. Bed Planting course. CIMMYT, Apdo. \# 370, P.O. Box 60326, Houston, TX 77205, Mexico. 